\title{
Thenardite after mirabilite deposits as a cool climate indicator in the geological record: lower Miocene of central Spain
}

\author{
M. J. Herrero ${ }^{1}$, J. I. Escavy ${ }^{1}$, and B. C. Schreiber ${ }^{2}$ \\ ${ }^{1}$ Departamento de Petrología y Geoquímica, Fac. Ciencias Geológicas, Universidad Complutense Madrid, \\ C/Jose Antonio Novais 2, 28040 Madrid, Spain \\ ${ }^{2}$ Department of Earth and Space Sciences, University of Washington, Seattle, WA 98195, USA \\ Correspondence to: J. I. Escavy (jiescavy@ucm.es)
}

Received: 15 July 2014 - Published in Clim. Past Discuss.: 11 August 2014

Revised: 17 November 2014 - Accepted: 26 November 2014 - Published: 5 January 2015

\begin{abstract}
Salt deposits are commonly used as indicators of different paleoclimates and sedimentary environments, as well as being geological resources of great economic interest. Ordinarily, the presence of salt deposits is related to warm and arid environmental conditions, but there are salts, like mirabilite, that form by cooling and a concentration mechanism based on cooling and/or freezing. The diagenetic transformation of mirabilite into thenardite in the upper part of the lower Miocene unit of the Tajo basin (Spain) resulted in the largest reserves of this important industrial mineral in Europe. This unit was formed in a time period $(\sim 18.4 \mathrm{Ma})$ that, in other basins of the Iberian Peninsula, is characterized by the existence of particular mammal assemblages appropriate to a relatively cool and arid climate. Determining the origin of the thenardite deposits as related to the diagenetic alteration of a pre-existing mirabilite permits the establishment and characterization of the sedimentary environment where it was formed and also suggests use as a possible analog with comparable deposits from extreme conditions such as Antarctica or Mars.
\end{abstract}

\section{Introduction}

Salt deposits are natural chemical deposits that have significant economic, scientific and social implications (Herrero et al., 2013; Warren, 2006). They constitute or contain valuable geological resources such as industrial minerals and building materials, and they are both a source and cap rock of hydrocarbons, etc. (Warren, 2010). It is commonly accepted that most salt deposits are formed under arid environmental conditions, being that most salts are produced in hot arid climates. For some saline deposits, this is the case, but there are many examples in current settings being produced under arid but cool conditions (Dort and Dort, 1970; Last, 1994; Socki et al., 2012; Stankevich et al., 1990; Zheng et al., 2000), and a few are not really evaporites, although they may appear so, superficially, but are pressure and thermal hydrothermal release precipitates (Chaboureau et al., 2012; Hovland et al., 2006).

Saline deposits have proved to be very useful in the study of paleoclimatology and sedimentology (Babel and Schreiber, 2014; Escavy et al., 2012; Fan-Wei et al., 2013; Kendall, 1992; Lowenstein et al., 1999; Minghui et al., 2010; Rouchy and Blanc-Valleron, 2009; Schreiber and El Tabakh, 2000; Warren, 2010). These studies are focused on the relationship between the main periods of the Earth's history with salt deposit formation and climate, which is one of the key factors involved in their deposition. Particularly, continental deposits in arid closed basins may record very accurately the changes in paleoclimate, being the most important factors controlling these changes the water inflow-outflow ratio, temperatures, wind patterns, storm records, and evaporation rates (Lowenstein et al., 1999). Comparison of salt deposits from lakes with marine records permits the development of land-sea correlations in the perspective of global reconstructions of environmental and climatic changes (Magny and Combourieu Nebout, 2013).

Most studies point to evaporative concentration as the main mechanism controlling precipitation of salts. Evaporitic salts precipitate after salt saturation of brines, and indicate hydrological systems in which evaporative water loss 
is greater than water gain. An alternative way to concentrate brine is by cooling-freezing processes that remove water from it through ice formation. These two concentration mechanisms lead to two different salt formation pathways: evaporative and "frigid" concentration (Strakhov, 1970). In addition, precipitation of certain salts occurs due to their reduction in solubility with temperature decrease (positive temperature coefficient of solution). The resultant minerals, like epsomite, sylvite and hexahydrite, are called cryophile salts (Stewart, 1963) or cryophilic salts (Sánchez-Moral et al., 2002). The main difference between salt deposits formed under cool or hot temperatures is the resulting mineral assemblage (Zheng et al., 2000), indicating the high dependence of the resultant mineralogy on the mechanism of brine concentration.

Sodium sulfate minerals appear to be highly dependent on temperature range (Dort and Dort, 1970), the anhydrous phase being the most common, $\mathrm{Na}_{2} \mathrm{SO}_{4}$ (thenardite), and two hydrated forms, $\mathrm{Na}_{2} \mathrm{SO}_{4} \times 7 \mathrm{H}_{2} \mathrm{O}$ (sodium sulfate heptahydrate) and $\mathrm{Na}_{2} \mathrm{SO}_{4} \times 10 \mathrm{H}_{2} \mathrm{O}$ (mirabilite). Both thenardite and mirabilite occur extensively in nature, while the heptahydrate is metastable and does not form or become preserved as natural deposits (Dort and Dort, 1970). Attempts to classify evaporitic minerals by their temperature of formation was proposed by Zheng et al. (2000), with mirabilite $\left(\mathrm{Na}_{2} \mathrm{SO}_{4} \times 10 \mathrm{H}_{2} \mathrm{O}\right)$ being the typical product of cool periods, bloedite $\left(\mathrm{Na}_{2} \mathrm{Mg}\left(\mathrm{SO}_{4}\right)_{2} \times 4 \mathrm{H}_{2} \mathrm{O}\right)$ for slightly warm phases, and thenardite $\left(\mathrm{Na}_{2} \mathrm{SO}_{4}\right)$ being formed under warm conditions. This work has been the first attempt to classify minerals by their temperature of formation, but the precipitation of saline minerals should always be related to the environmental and geological conditions of the salt deposit because their temperature of formation may vary from one setting to another.

Mirabilite, therefore, is the most common evaporitic mineral crystallizing under cool temperatures (Nai'ang et al., 2012; Wang et al., 2003; Zheng et al., 2000). An example is the mirabilite layers from the Huahai lake (China), where they precipitated under mean temperatures around $11^{\circ} \mathrm{C}$ lower than current ones, during the Quaternary Younger Dryas event (Nai'ang et al., 2012). Thenardite, however, is the most common sodium sulfate found in ancient deposits (Garrett, 2001), occurring mostly in Neogene continental endorheic settings (Warren, 2010). As a primary mineral, it forms either by direct precipitation from warm brines in shallow lakes (Last, 1994), either in/or near the surface of playas as capillary efflorescent crusts by evaporative concentration (Jones, 1965). It commonly occurs as thin layers interbedded with other evaporitic minerals forming salt assemblages (Garrett, 2001). In Lake Beida (Egypt), thenardite occurs as a $50 \mathrm{~cm}$ thick crust together with halite $(\mathrm{NaCl})$, trona $\left(\mathrm{Na}_{3}\left(\mathrm{CO}_{3}\right)\left(\mathrm{HCO}_{3}\right) \times 2\left(\mathrm{H}_{2} \mathrm{O}\right)\right)$ and burkeite $\left(\mathrm{Na}_{6}\left(\mathrm{CO}_{3}\right)\left(\mathrm{SO}_{4}\right)_{2}\right)$ (Shortland, 2004).

Therefore, both mirabilite and thenardite precipitate in modern lacustrine systems, whereas only thenardite appears as the prevalent sodium phase in the geological record (Ortí et al., 2002). Mirabilite is a very reactive mineral due to its low melting point and high solubility (Garrett, 2001), this being the main reason for the lack of this mineral in ancient deposits. When the conditions where mirabilite has accumulated change (increase in temperature, evaporation rate, burial, interaction with concentrated salt solutions, etc.), it melts, dissolves, or is transformed into more stable minerals such as thenardite, astrakanite (bloedite), glauberite $\left(\mathrm{Na}_{2} \mathrm{Ca}\right.$ $\left.\left(\mathrm{SO}_{4}\right)_{2}\right)$ or burkeite (Garrett, 2001).

The Oligocene-lower Miocene sequence of the Tajo basin contains a 100 to $650 \mathrm{~m}$ thick succession of evaporitic materials (Calvo et al., 1989) that include one of the major thenardite deposits of the world (Garrett, 2001). This paper presents the results of the analysis of this thenardite deposit and establishes its secondary origin as a transformation phase after mirabilite. As a result, we postulate that the thenardite level within the lower Miocene lacustrine sequence is a cool paleotemperature indicator. Therefore, we have been able to identify a decrease in temperature and precipitation regime in the lower Miocene geological record of the Iberian Peninsula during which there also was a significant change in faunal diversity, coincident with the Mi1a event of Miller et al. (1991) that took place at $18.4 \mathrm{Ma}$ that is well documented on a worldwide scale (Zachos et al., 2001).

\section{Study site}

The Tajo basin, located in the central part of the Iberian Peninsula (Fig. 1), was formed during the Cenozoic by several basement uplifts (De Vicente et al., 1996). Growth strata related to syntectonic alluvial deposits appear in the margins of the basin and pass into lacustrine and palustrine deposits towards the center (Calvo et al., 1989). Ordoñez and García del Cura (1994) defined four main units in the Neogene of the Tajo basin: a Lower or Saline Unit, an Intermediate or Middle Unit, and Upper Miocene Units and the Pliocene Unit. Based on the study of cores from several drill holes, they divided the Lower Unit into a Lower Saline Subunit that occupies a broad area of the Tajo basin, and the Upper Saline Subunit that contains the thenardite deposits, which is restricted to the area south of the Tajo River.

During the lower Miocene (23.2-16.2 Ma), the Lower Unit was formed by syntectonic coarse alluvial detrital deposits located close to the tectonically active margins of the basin, gradually passing into finer clastic sediments (sandstones and shales) and wide saline lake systems that occupied the basin center (Calvo et al., 1996). The saline deposits, a succession up to $500 \mathrm{~m}$ thick, are composed of alternating anhydrite, halite and glauberite beds with some thin layers of fine interbedded detritic sediments. This unit grades laterally into shale beds with abundant calcium sulfate nodules (of both gypsum and anhydrite), followed by 


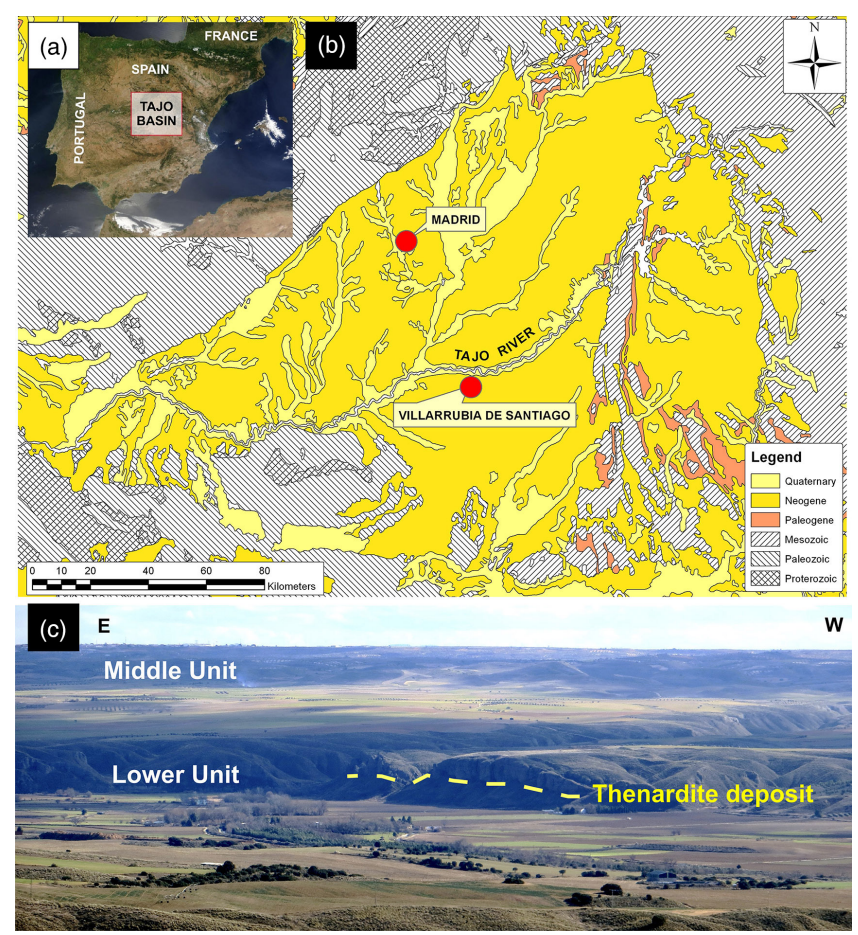

Figure 1. (a) Location of the Tajo basin in the central part of the Iberian Peninsula. (b) Simplified geological map of the Tajo basin and surrounding mountain belts (modified from the Spanish Geological Map, scale 1:50000, IGME, 2013). The thenardite deposits appear near the village of Villarrubia de Santiago. (c) General view of the upper part of the Lower Unit and the base of the Middle Unit of the Miocene sequence of the Tajo basin in the Villarrubia de Santiago area. The thenardite deposit is laterally continuous for tens of kilometers, although, due to the high solubility of the thenardite, it is not easily identified at all locations.

coarsersiliciclasticdeposits that correspond to alluvial fans formed at the foot of the surrounding mountain ranges. To the south of the Tajo River valley, the upper part of the Lower Unit (Fig. 2a, b) contains a massive deposit of thenardite, 7-12 m thick (Fig. 2b, c) (Ortí et al., 1979). This thenardite overlies a massive halite and decimeter-thick beds of glauberite. Thus, unlike the broadly distributed glauberite, the deposit of thenardite is restricted to a relatively small area in the central part of the basin (Ordóñez et al., 1991). Above the thenardite layer, there is a layer of mirabilite (several $\mathrm{cm}$ thick), a product of recent hydration of the thenardite by meteoric water (Ortí et al., 1979). At the top of the Lower Unit, there is a $10-20 \mathrm{~m}$ thick alternation of layers (tens of $\mathrm{cm}$ ) composed of secondary gypsum, both alabastrine (Fig. 2d) and macro-crystalline (Fig. 2e), interbedded with shales and marls. This unit has been interpreted as a weathering cover, a product of the replacement of glauberite and anhydrite by gypsum (Ordoñez and García del Cura, 1994). The top of the Lower Unit is established at a paleokarstic surface (Cañaveras et al., 1996).
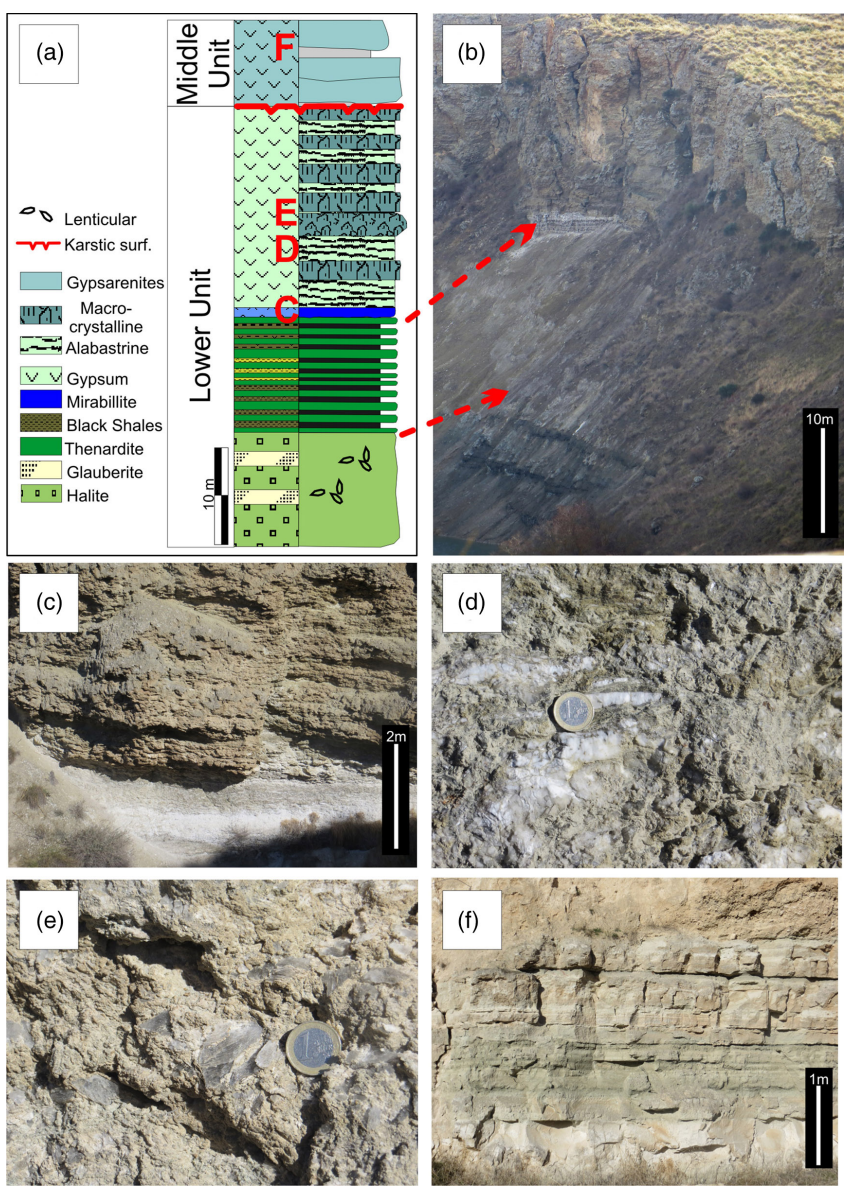

Figure 2. (a) Stratigraphic section of the upper part of the Lower Unit and the lowermost part of the Middle Unit of the Miocene in the Tajo basin. (b) General view of the Lower Unit outcropping along the current Tajo River (south bank). (c) Outcrop view of the contact between the upper part of the thenardite body and the overlaying unit with secondary gypsum. This secondary gypsum appears as two main lithofacies: (d) alabastrine gypsum, and (e) macro-crystalline gypsum (the coin for scale is $2.2 \mathrm{~cm}$ in diameter). (f) Outcrop of the detritic gypsum beds that comprise the lower part of the Middle Unit.

Higher up in the sequence, the Miocene Middle Unit is mostly composed of primary gypsum forming tabular beds up to $1 \mathrm{~m}$ thick (Fig. 2f). This unit passes upwards into abundant carbonate bodies and is characterized by the absence of evaporitic minerals such as halite or glauberite. During this period, there was a significant progradation of siliciclastic sediments that reached the central part of the basin. Sedimentation during the Miocene Upper Unit was dominated by carbonates and marls (Calvo et al., 1996). 


\section{Materials and analytical methods}

\subsection{Sampling}

A total of 30 samples have been collected from different levels of the evaporitic sequence, both from the subsurface mine walls and from drilled cores provided by SAMCA, the company that owns the sodium sulfate deposit. The thenardite samples were collected from the mine face, while the haliteglauberite samples have been obtained from exploration drill cores. In order to avoid the alterations produced during drilling (by the interaction with drilling fluids, the pressure and heat transmitted by the coring bits, etc.), only the centermost part of the core has been used. Special care has been taken during sample preparation in order to prevent mineral alteration, avoiding high temperatures $\left(>25^{\circ} \mathrm{C}\right)$ and exposure to humid conditions.

\subsection{Optical microscopy and SEM analysis}

For the petrographic study, rock samples were cut with an oil-refrigerated $1 \mathrm{~mm}$ thick diamond disc saw (Struers Discoplan-TS). A low viscosity oil was used (rhenus GP 5M) for cutting, grinding and polishing. When cutting samples in the disc saw, extra rock was included at the cut $(\sim 1 \mathrm{~mm})$ and was removed by hand grinding, thus eliminating any possible alteration of the samples. Grinding to the final thickness has been done using emery papers with different grit sizes, impregnated with oil. Unconsolidated samples were previously indurated with a resin under vacuum (Struers Epofix resin). The thin sections were glued on $4.8 \mathrm{~cm} \times 2.8 \mathrm{~cm}$ glass slides using LOCTITE 358, and cured afterwards under ultraviolet light.

Petrographic characterization was performed using a Zeiss West Germany Optical 316 Microscope (OM) at the Department of Petrology and Geochemistry of Complutense University of Madrid (UCM). By analyzing the doubly polished plates, it has been possible to undertake a petrographic characterization of fluid inclusions, determining the moment of formation in relation to the crystal growth.

Textural characterization of the samples was completed by scanning electron microscopy observations performed using a JEOL 6.400 instrument working at $20 \mathrm{kV} 320 \mathrm{mi}-$ croscopy (SEM), at the CAI Geological Techniques Laboratory (UCM).

\subsection{X-Ray diffraction analysis}

To obtain the whole rock mineralogy by X-ray diffraction, a portion of 20 of the 30 samples was ground in an agate mortar at low rotation speed (avoiding high temperatures). A Bruker D8 Advance diffractometer equipped with a Sol-X detector was used. The mineralogical composition of crystalline phases was estimated following Chun's (1975) method and using Bruker software (EVA). The XRD analysis was performed at the Geological Techniques Laboratory (UCM).

\subsection{Low-temperature scanning electron microscopy (LTSEM)}

This technique was used to assess the chemical composition of fluid inclusions and to establish qualitatively and quantitatively the elemental characterization of the host minerals and the fluid inclusion fluids (Ayora et al., 1994). Lowtemperature scanning electron microscopy (LTSEM or CryoSEM) was performed in 20 fluid inclusions from 11 samples using small pieces of thenardite and halite that were cut, mounted, and mechanically fixed onto a specimen holder at room temperature. The instrument used was a CT 1500 Cryotrans system (Oxford Instruments) mounted on a Zeiss 960 SEM. This study was done at the Spanish Institute of Agricultural Sciences (ICA) of the CSIC.

\section{Results}

\subsection{Mineralogy}

The lower part of the Lower Unit sequence, below the thenardite deposit (Fig. 3a), is characterized by evaporitic layers composed of a mixture of glauberite $(45.8 \%)$ and halite $(41.7 \%)$ (Fig. 3b), with a minor content of polyhalite $(7.8 \%)$, dolomite $(2.1 \%)$, and clay minerals $(1.8 \%)$ (Table 1). This mineral assemblage is common in evaporitic Neogene continental basins of the Iberian Peninsula such as those of the Zaragoza (Salvany et al., 2007) or Lerín gypsum formations (Salvany and Ortí, 1994), both in the Ebro basin (Spain). The relative proportions of halite and glauberite are variable, with halite ranging from 30 to $51 \%$ and glauberite from 23 to $59 \%$. Glauberite crystals (Fig. 3b), with sizes between $1 \mathrm{~mm}$ and $10 \mathrm{~cm}$, occur either forming banded or nodular layers with abundant structures indicating fluid escape, or as irregular masses or nodules accompanying halite crystals in the halite-rich horizons (Fig. 3b). No stratification or competitive growth typical of primary halite formation is found. Therefore, a secondary origin of these halite crystals can be inferred.

Higher up in the sequence, a sharp change in mineralogy takes place, passing upward into a fairly pure and thick sodium sulfate body mainly composed of thenardite $(96.5 \%)$ with a minor content of glauberite $(2.5 \%)$ and anhydrite $(1.0 \%)$ (Table 1). Thenardite (Fig. 3c) occurs as cm-sized subeuhedral to anhedral crystals, with sizes from $1 \mathrm{~mm}$ to several $\mathrm{cm}$, forming aggregates. Crystal color is also variable, ranging from blue to clear and transparent. When crystals have a high volume of fluid inclusions, they have a cloudy aspect. Thenardite layers usually present abundant fluid escape structures (Ortí et al., 1979).

\subsection{Fluid inclusion analysis}

Fluid inclusions are abundant within the thenardite and halite crystals, whereas they are very scarce in the 
Table 1. XRD mineralogical composition of the samples.

\begin{tabular}{|c|c|c|c|c|c|c|c|}
\hline \multirow[b]{2}{*}{ Sample ID } & \multicolumn{7}{|c|}{ Halite-glauberite layer } \\
\hline & Thenardite & Glauberite & Halite & Polyhalite & Dolomite & Anhydrite & Clay Min. \\
\hline $522116-01$ & - & 45.7 & 30.2 & 19.6 & 2.6 & - & 0.0 \\
\hline 522116-02 & - & 23.5 & 51.1 & 12.1 & 5.9 & - & 7.4 \\
\hline $522116-03$ & - & 54.9 & 45.1 & 0.0 & 0.0 & - & 0.0 \\
\hline 522116-04 & - & 59.4 & 40.6 & 0.0 & 0.0 & - & 0.0 \\
\hline $522116-10$ & - & 51.5 & 47.5 & 0.0 & 0.0 & - & 1.0 \\
\hline \multirow[t]{2}{*}{ Mean } & - & 47.0 & 42.9 & 6.3 & 1.7 & - & 1.7 \\
\hline & \multicolumn{7}{|c|}{ Thenardite layer } \\
\hline 522116-05 & 100.0 & 0.0 & - & - & - & - & - \\
\hline 522116-06 & 91.3 & 5.5 & - & - & - & 3.2 & - \\
\hline $522116-07$ & 99.0 & 1.0 & - & - & - & - & - \\
\hline $522116-08$ & 95.8 & 3.2 & - & - & - & 1.0 & - \\
\hline $522116-09$ & 99.0 & 1.0 & - & - & - & - & - \\
\hline $522116-11$ & 95.0 & 3.6 & - & - & - & 1.4 & - \\
\hline 522116-12 & 91.3 & 5.5 & - & - & - & 3.2 & - \\
\hline $522116-13$ & 99.5 & 0.5 & - & - & - & - & - \\
\hline 522116-14 & 99.0 & 1.0 & - & - & - & - & - \\
\hline 522116-15 & 94.6 & 3.8 & - & - & - & 1.6 & - \\
\hline 522116-16 & 92.9 & 5.0 & - & - & - & 2.1 & - \\
\hline 522116-17 & 100.0 & - & - & - & - & - & - \\
\hline 522116-18 & 94.5 & 4.4 & - & - & - & 1.1 & - \\
\hline 522116-19 & 98.2 & 1.0 & - & - & - & 0.8 & - \\
\hline 522116-20 & 97.3 & 1.7 & - & - & - & 1 & - \\
\hline Mean & 96.5 & 2.5 & - & - & - & 1.0 & - \\
\hline
\end{tabular}

glauberitecrystals. Most of them are primary fluid inclusions that were formed during the growth of the crystals. Therefore, the brine trapped in the primary fluid inclusions is the same from which these minerals precipitated. In the case of diagenetic minerals, fluid inclusions show the conditions of recrystallization rather than the conditions of formation of the precursor mineral (Goldstein and Reynolds, 1994). There appear to be few primary inclusions in the form of twophase inclusions (containing gases or solids), most of them being single-phase aqueous liquid inclusions at room temperature.

In this study, only primary fluid inclusions have been analyzed, established as primary by their relationship with the crystals' growth zonation (Fig. 3d), mainly because voids that house these fluid inclusions are crystallographically regular (mimic crystal terminations) (Goldstein and Reynolds, 1994). Some sparse secondary fluid inclusions have been found aligned or associated with fractures.

The primary fluid inclusion chemical composition has been analyzed by Cryo-SEM. Fluid aqueous inclusions analyzed (15 analyses) in the thenardite crystals (Fig. 3e, f) have shown that, systematically, the only elements found in the brine are $\mathrm{Na}$ and $\mathrm{S}$ (Fig. $3 \mathrm{~g}$ ). The composition obtained by analyzing the fluid inclusions from the halite crystals (five analyses) is $\mathrm{Na}$ and $\mathrm{Cl}$, with trace contents of $\mathrm{Ca}$ (Fig. 3h).

\section{Discussion}

\subsection{Dates and climate during the thenardite formation}

The formation of the many Cenozoic lacustrine systems in Spain was mainly controlled by the tectonic activity that affected the Iberian microplate and by changes in the paleogeography and paleoclimatic conditions of the western Mediterranean-eastern Atlantic zone (De Vicente et al., 1996). The base of the Lower Unit of the Miocene (the Lower Saline Subunit) of the Tajo basin is at the OligoceneMiocene boundary ( $\sim 23 \mathrm{Ma})$ and ends at the top of the Burdigalian stage ( 16 Ma) (Calvo et al., 1993). Paleoclimatic curves have been obtained through the study of mammal associations (Calvo et al., 1993; Daams and Freudenthal, 1988; Van der Meulen and Daams, 1992), and show that this period was warm and humid and became relatively more arid towards its end. Nevertheless, within this unit, the temperature and humidity curves for northern-central Spain (Van der Meulen and Daams, 1992) show the existence of a stage where both temperature and humidity were reduced. The thenardite of this study appears within the sequence that corresponds to this time period. Previous authors (Calvo et al., 1996; Ordóñez et al., 1991) have interpreted the thenardite layer as the result of thermal evaporative concentration when 

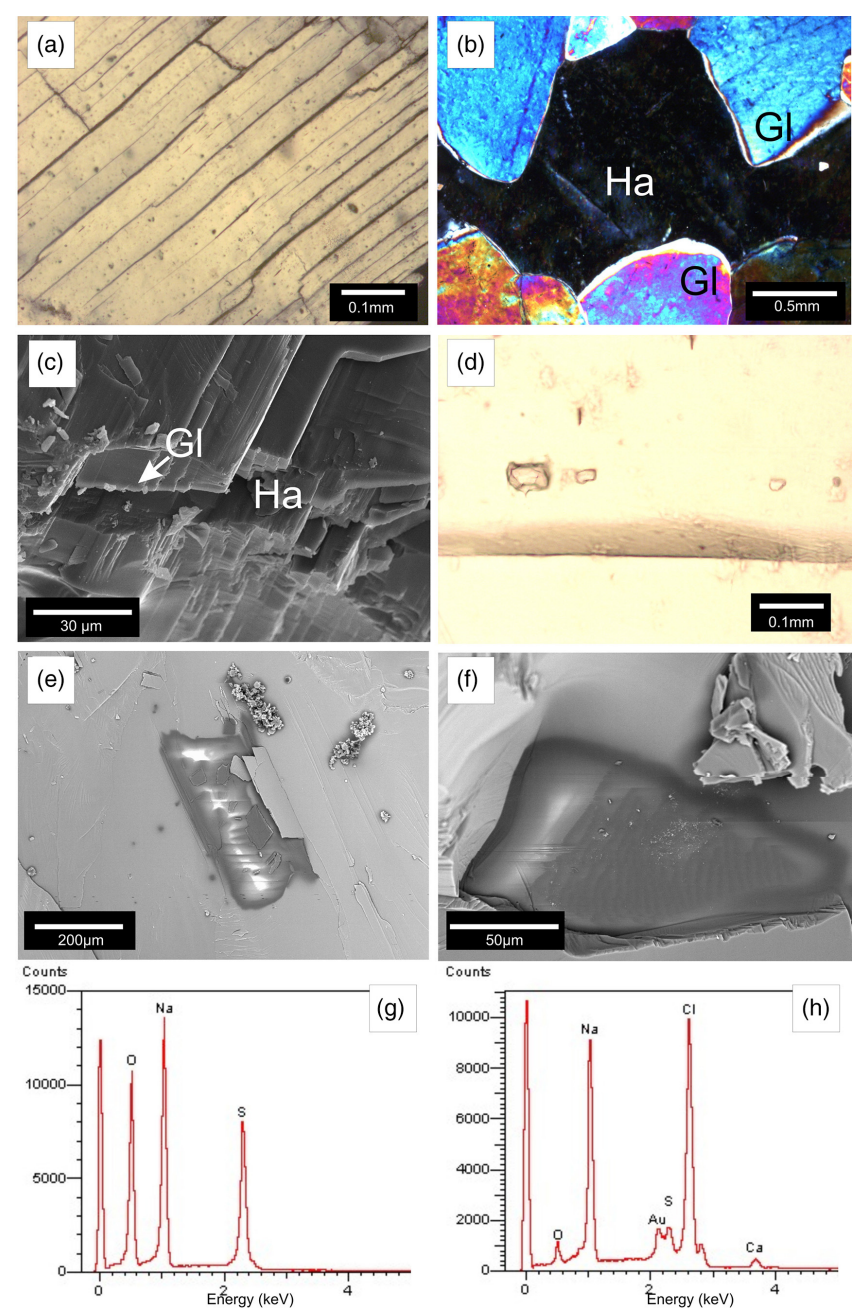

Figure 3. (a) Thenardite crystal under a thin section (crossed nicols) with a splintery fracture along cleavage planes. (b) Photomicrograph of idiomorphic crystals of glauberite $(\mathrm{Gl})$ cemented by halite (Ha) (crossed nicols). (c) SEM image of a thenardite crystal showing splintery fractures along cleavage planes. (d) Photomicrograph of primary fluid inclusions in a thenardite crystal mimicking the thenardite crystal termination. (e) and (f): frozen fluid inclusion within thenardite crystals studied by Cryo-SEM SEM. (g) EDX spectrum of a fluid inclusion in a thenardite crystal with sodium and sulfate as the only ions present, analyzed by Cryo-SEM. (h) CryoSEM EDX spectrum of a fluid inclusion in the halite, containing sodium, chlorine and low quantities of sulfate and calcium ions.

the lake water volume was reduced, although they indicated that the environments required to follow this brine concentration path do not fit with the temperature and humidity curves proposed for that time span in other parts of the Iberian Peninsula. This difference in environmental conditions has been explained as the establishment of a microclimate in this area, placed in a "rain shadow" region that resulted from the uplift of the surrounding mountain belts (Ordóñez et al., 1991) and also the existence of highly concentrated brines sourced by recycling of older evaporites (Calvo et al., 1996). Ordoñez and García del Cura (1994) suggested, as one of the options for the formation of the thenardite deposit, that mirabilite formed within these lakes could have been transformed into thenardite during early diagenesis.

\subsection{Evaporative concentration versus frigid precipitation: mineralogical criteria}

Salt precipitation from a given aqueous solution undersaturated with respect to a given mineral can be achieved in three different ways: (1) removal of the solvent (water) at more or less constant temperature by evaporation (evaporative concentration); (2) removal of water by freezing, called frigid concentration, producing cryogenic salts according to Strakhov (1970); and (3) change in temperature at constant salinity (or total concentration) producing the precipitation of cryophilic salts, according to Borchert and Muir (1964). By the first two mechanisms, there is an increase in the concentration of all the dissolved species, leading to the formation of a brine. The third mechanism, related to changes in mineral solubility with temperature, only modifies the concentration of the dissolved species that constitute the precipitating mineral. The second mechanism (freezing) compulsorily implies the third one (solubility change with $T$ ), and therefore they should be able to happen together in natural environments.

These distinct pathways of brine concentration result in two different pathways of salt formation: by evaporation of the solvent (evaporative concentration) or by cooling/freezing (frigid concentration). Nevertheless, the resulting mineralogy is obviously also dependent on the ion content of the mother brine (Eugster and Hardie, 1978; Hardie and Eugster, 1970).

When a brine is concentrated by evaporation, the salt content increases, reaching saturation and precipitating progressively from less soluble to more soluble minerals. If evaporation continues, at the eutonic point all the remaining salts precipitate simultaneously. In natural conditions with natural brines the eutonic point is reached at temperatures above $32^{\circ} \mathrm{C}$, with salinities between 35 and $40 \%$ (Strakhov, 1970).

The freezing process concentrates the brine in the same way as by evaporation, by removing $\mathrm{H}_{2} \mathrm{O}$ from the solution, but in this case by formation of ice, leading to a concentrated residual brine as well as the progressive precipitation of saline minerals (Stark et al., 2003). Freezing ends when the eutectic or cryohydric point is reached, at the point when all compounds (including $\mathrm{H}_{2} \mathrm{O}$ ) pass to the solid state (Mullin, 2001). Depending on the initial mineralization and composition of the brine, the eutectic point is reached between -21 and $-54^{\circ} \mathrm{C}$ (Marion et al., 1999; Strakhov, 1970). The liquid brines, called cryobrines, are those that reach the eutectic point at temperatures below $0{ }^{\circ} \mathrm{C}$ (Möhlmann and Thomsen, 2011), and such brines exist in the Earth's polar regions 

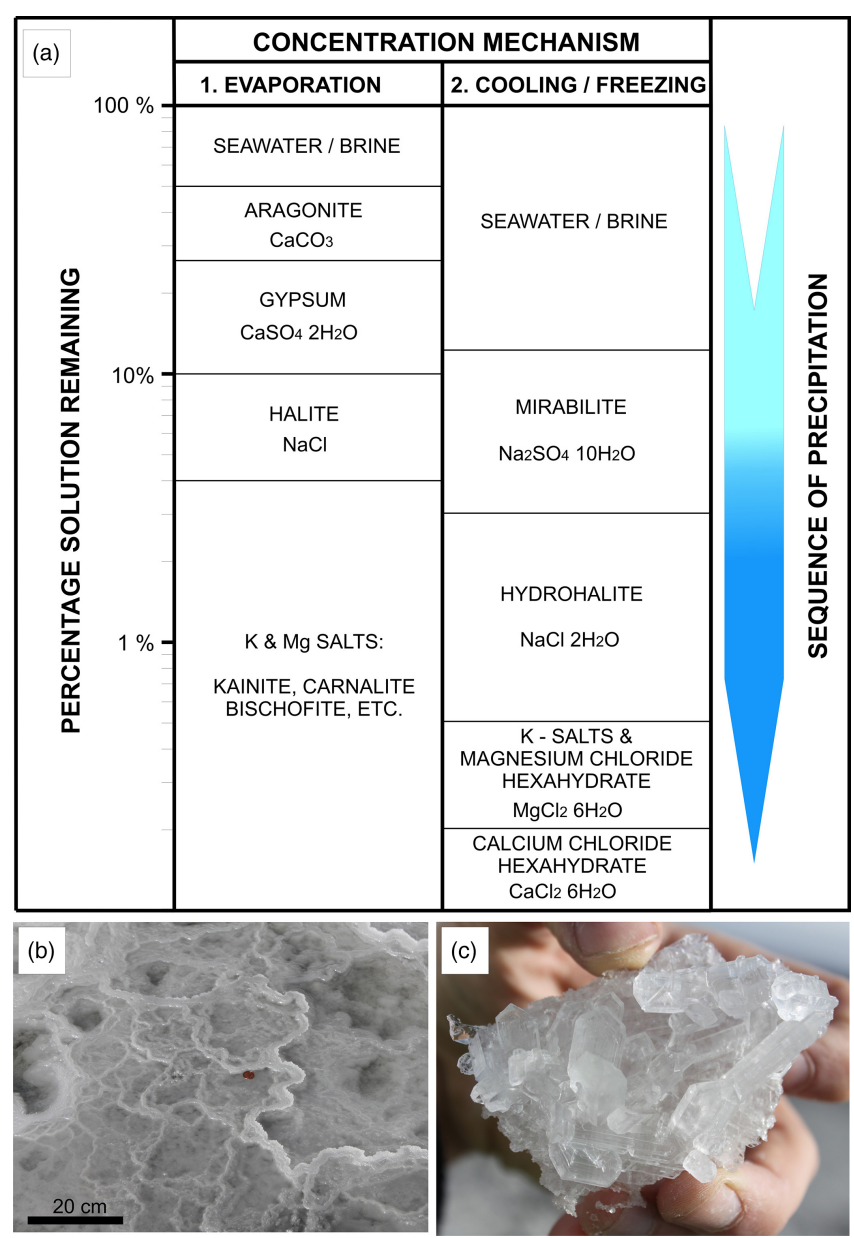

Figure 4. (a) Mineral precipitation sequences from seawater depending on the concentration mechanism. Arrow shows the sense of precipitation. Left scale (logarithmic) shows the percentage of remaining brine during the concentration process. Evaporative concentration sequence defined by Orti (2010) and frigid concentration by Dort and Dort (1969). (b) and (c): mirabilite precipitation in a pond near a $\mathrm{Na}_{2} \mathrm{SO}_{4}$-rich water spring in Belorado (Burgos, Spain). Photographs taken early in the morning after 3 days of continuous cool temperatures (30 November 2011). General view of the mirabilite pond (b). See coin as scale (diameter $1.8 \mathrm{~cm}$ ). Detail of the mirabilite crystals (c).

(Garrett, 2001) and probably on Mars (Peterson et al., 2007). The minerals formed under these conditions are called cryogenic (Babel and Schreiber, 2014; Brasier, 2011).

Sodium salts precipitate in nature by both mechanisms: (1) concentration of the brine by solar-driven evaporation like in the Quaternary playas of the USA, and (2) by brine cooling and freezing, like in Kara Bogaz Gol in Turkmenistan, and the Great Plains of Canada (Last, 1994; Warren, 2010).

The different results obtained from the same brine, by using evaporative or frigid concentrations, can be illustrated with the different resultant mineral paragenesis obtained from the seawater (Fig. 4a). Path 1 is the result of evaporative concentration: calcite $\left(\mathrm{CaCO}_{3}\right)-$ gypsum $\left(\mathrm{CaSO}_{4} \times 2 \mathrm{H}_{2} \mathrm{O}\right)$ - halite $(\mathrm{NaCl})$ and, finally, the bittern salts $(\mathrm{K}$ and $\mathrm{Mg}$ salts) (Harvie et al., 1980; Ortí, 2010); path 2 is the result of frigid concentration: mirabilite $\left(\mathrm{Na}_{2} \mathrm{SO}_{4} \times 10 \mathrm{H}_{2} \mathrm{O}\right)-$ hydrohalite $\left(\mathrm{NaCl} \times 2 \mathrm{H}_{2} \mathrm{O}\right)$ - sylvite $(\mathrm{KCl})$ and $\mathrm{MgCl}_{2} \times 6 \mathrm{H}_{2} \mathrm{O}$ $-\mathrm{CaCl}_{2} \times 6 \mathrm{H}_{2} \mathrm{O}$ (Dort and Dort, 1970). Recently, a new sequence of precipitation for frigid concentrations of seawater has been proposed, named the Gitterman pathway (Marion et al., 1999), which consists of mirabilite $\left(\mathrm{Na}_{2} \mathrm{SO}_{4} \times 10 \mathrm{H}_{2} \mathrm{O}\right)$ - gypsum $\left(\mathrm{CaSO}_{4} \times 2 \mathrm{H}_{2} \mathrm{O}\right)$ - hydrohalite $\left(\mathrm{NaCl} \times 2 \mathrm{H}_{2} \mathrm{O}\right)$ - sylvite $(\mathrm{KCl})$ and $\mathrm{MgCl}_{2} \times 12 \mathrm{H}_{2} \mathrm{O}$, which also offers a significantly different mineral paragenesis to the one obtained by evaporative concentration from seawater. Nevertheless, the final mineralogy that is found in the geological record depends not only on the primary mineralogy, but also on the diagenetic history of the rock (Schreiber and El Tabakh, 2000).

\subsubsection{Precipitation of mirabilite}

Attempts to classify evaporitic minerals by their temperature of formation have been carried out by Zheng et al. (2000), with mirabilite being the typical product of cool periods, bloedite for slightly warm phases and primary thenardite indicative of warm phases. If the mean annual air temperature is lower than $-3{ }^{\circ} \mathrm{C}$, it is possible for the newly created mirabilite layers to persist (Wang et al., 2003). With at least 7 months of mean temperatures below $0{ }^{\circ} \mathrm{C}$, it is possible to obtain thick mirabilite layers, although they are unstable through the rest of the year and would not persist in time. Therefore, only thick mirabilite beds that have undergone the temperature conditions necessary for the precipitation and preservation of this mineral can be indicators of sustained cool periods (Minghui et al., 2010).

The sodium sulfate solubility curve shows a rapid decrease when the temperature drops (Dort and Dort, 1970), resulting in mirabilite crystallization from concentrated brines during cool temperature periods like in glacial periods or during fall and winter at high latitudes. Thick beds of mirabilite are common in modern Canadian playa lakes (Last, 1994, 1984). Mirabilite may naturally crystallize even from diluted brines such as seawater if temperature drops severely (Garrett, 2001). This is the case in the McMurdo area, Antarctica, where average air temperatures are about $-20^{\circ} \mathrm{C}$. Mirabilite precipitates at higher temperatures from more concentrated brines (Garrett, 2001). In Ebeity Lake in Siberia (Russia), mirabilite starts forming at the end of the summer when the brine temperature drops below $19^{\circ} \mathrm{C}$ (Strakhov, 1970). When the environmental temperature of $0{ }^{\circ} \mathrm{C}$ is reached, $70 \%$ of the mirabilite has already precipitated, and almost all the mirabilite has formed when temperature reaches $-15^{\circ} \mathrm{C}$. If the brine continues freezing, hydrohalite precipitates at $-21.8^{\circ} \mathrm{C}$ (Strakhov, 1970). We have recorded mirabilite current precipitation in Burgos (northern Spain) at a height of $820 \mathrm{~m}$ a.s.l. under night-time temperatures between -2 and 
$0{ }^{\circ} \mathrm{C}$. At this location, mirabilite precipitates in ponds as microterraces (Fig. 4b, c) that form from emergent groundwater that flows through Cenozoic glauberite deposits.

\subsubsection{Precipitation of thenardite}

From the range of sodium sulfate minerals, thenardite is the most commonly found in ancient deposits (Garrett, 2001). Thenardite can be formed as a primary mineral by direct precipitation from warm brines in shallow lakes (Last, 1994), or as capillary efflorescent crusts in playas with sulfate-rich waters (Jones, 1965). Primary thenardite normally occurs together with many other evaporitic minerals forming salts assemblages (Garrett, 2001), usually as layered evaporite deposits like in Lake Beida, Egypt (Shortland, 2004). According to Lowenstein and Hardie (1985), layered evaporites can accumulate in (1) ephemeral saline pans, (2) shallow perennial lagoons or lakes, and (3) deep perennial basins. Evaporitic sediments occurring in saline pans consist of centimeter-scale crystalline salt levels, alternating with millimeter- to centimeter-scale detrital siliciclastic-rich muds. Thenardite precipitating in modern saline pans appears to be associated with halite, gypsum, mirabilite, epsomite and trona (Lowenstein and Hardie, 1985), and there are no thick deposits of pure thenardite described in the literature as being formed as a primary deposit. Lake Beida (Egypt) contains the purest primary thenardite deposit in the world, reaching $60 \%$ of thenardite at some locations, with variable contents of halite (up to $60 \%$ ), sodium carbonate (trona, up to $14 \%$ ), sodium bicarbonate (nahcolite, up to $16 \%$ ) and minor amounts of other $\mathrm{K}, \mathrm{Ca}$ and $\mathrm{Mg}$ salts (Nakhla et al., 1985).

Instead, thenardite can be formed by the transformation of other minerals during diagenesis (secondary thenardite), the most common case being the mirabilite dehydration by increasing temperature, evaporation rate, burial, or by interaction with $\mathrm{NaCl}$-concentrated brines (Last, 1994).

\subsubsection{Transformation: mirabilite to thenardite}

Mirabilite is a very reactive mineral due to its low melting point and high solubility (Garrett, 2001). This high reactivity is the main reason for the lack of this mineral in ancient deposits, because when the conditions of formation of mirabilite change, it usually dissolves or is transformed into other more stable minerals such as thenardite (Garrett, 2001). The mirabilite-to-thenardite transformation commonly takes place at about $32.4^{\circ} \mathrm{C}$, but in the presence of $\mathrm{NaCl}$, this transition occurs at approximately $18^{\circ} \mathrm{C}$ and drops down to $16^{\circ} \mathrm{C}$ if $\mathrm{Mg}^{2+}$ is present (Charykova et al., 1992). The impact of additional ions within the solution in the transition temperatures in the sodium sulfate system is due to the double salt effect (Warren, 2010). The transformation of mirabilite into thenardite may occur soon after deposition (in the early diagenesis) or later, when the change in the condi-

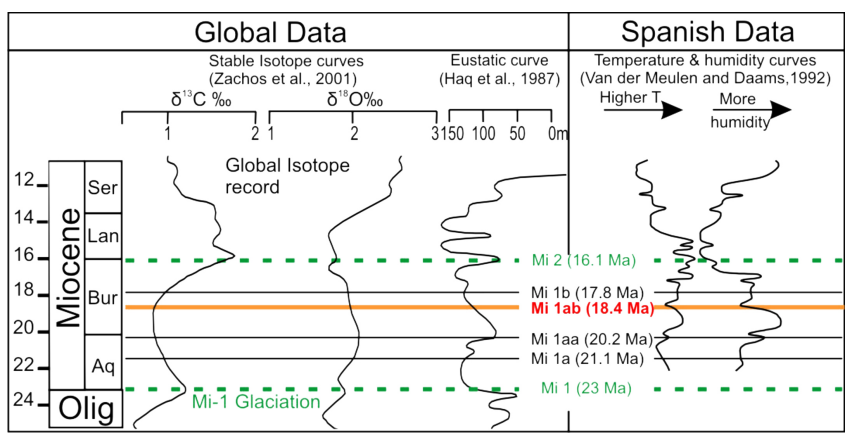

Figure 5. Correlation of the Oligocene-Miocene of the global deepsea carbon and oxigen isotope curves of Zachos et al. (2001), with the Haq et al. sea-level curve (Haq et al., 1987). The main significant ages of the Miocene oxigen isotope events (Mi events) are shown (Miller et al., 1991). The green Mi 1 event corresponds to the Oligocene-Miocene glaciation produced during the OligoceneMiocene limit. The red line corresponds to the Mi-1ab, the time at which the mirabilite deposits (thenardite precursor) of the Tajo basin were formed. The absolute ages are relative to the USGS Chronostratigraphic Chart (2013).

tions makes mirabilite unstable, for example by compaction during burial (Garrett, 2001). An example of an early diagenesis transformation is found in Kuchuk Lake (Russia), where mirabilite precipitates during the cool winters, and, during summers, the level of the lake drops due to evaporation and becomes $\mathrm{NaCl}$ saturated, producing the transformation into thenardite (Stankevich et al., 1990). Mirabilite can also be transformed into thenardite directly by heating upon burial (Warren, 2010). The water of crystallization of mirabilite, which escapes during the transformation into thenardite, produces fluid escape structures within the sedimentary sequence. Part of this water may also be trapped as fluid inclusions within the emerging thenardite crystals.

\subsubsection{Sedimentology and diagenesis}

There are several characteristics that indicate that mirabilite is the precursor mineralogy of the thenardite beds from the lower Miocene deposits of the Tajo basin. Textural features (Ordoñez and García del Cura, 1994; Ortí et al., 1979), mineral assemblage and fluid inclusion chemistry presented in this study suggest this mineral progression. This information, combined with paleontological evidence, is indicative of the existence of cool and arid environmental conditions at the time of formation, and therefore, it can be correlated with a time period having these characteristics.

The thenardite deposit of the Tajo basin commonly occurs as large crystals in thick and fairly pure layers that present fluid escape structures. The thenardite deposit appears as interbedded layers of pure thenardite ( $\mathrm{cm}$ to $\mathrm{m}$ thick) with thin intercalations of black shales (Ortí et al., 1979), similar to the sequence described in Lake Kuchuk in the Volga region of Russia (Stankevich et al., 1990). No textural characteristics 
such as dissolution (flooding stage), crystal growth (saline lake stage), or syndepositional diagenetic growth features (a desiccation stage) (Lowenstein and Hardie, 1985) have been found in the Tajo basin thenardite deposit, which would indicate a primary thenardite origin within a salt-pan environment. Instead, fluid escape structures appear that are indicative of the fluids produced during the mirabilite dehydration and transformation to thenardite.

\subsubsection{Fluid inclusions}

Primary fluid inclusions within evaporitic minerals contain and preserve samples of the brine where the crystals were growing. In our case, the chemistry of the fluid inclusions is mainly chlorine and sodium within the halite fluid inclusions, and sulfur and sodium within the thenardite ones. This is not surprising because, in aqueous fluid inclusions occurring in very soluble minerals, like the ones under study, the chemistry of the aqueous solution will very rapidly come to equilibrium with the surrounding mineral. Therefore, the fluid inclusion chemistry will contain a relevant amount of the ions forming the hosting minerals. The most common mineral precursor for diagenetic thenardite is the original hydrated sodium sulfate (mirabilite) (Dort and Dort, 1970). Part of the water of crystallization escapes, but another part may be trapped in the fluid inclusions that are formed during the growth process of the resulting thenardite crystals. The chemical composition of such aqueous inclusions should be exclusively water and ions from the hosting mineral (in this case, sodium and sulfate).

Previous studies of fluid inclusions in other primary salts of the Cenozoic sequences of the Tajo basin show a broad range of cations defining a mother brine rich in $\mathrm{Ca}^{2+}, \mathrm{Na}^{+}$, $\mathrm{Mg}^{2+}$ and $\mathrm{K}^{+}$(Ayllón-Quevedo et al., 2007). The fluid inclusions, within the thenardite crystals, exclusively contain the same ions as the host mineral (sodium and sulfate), highlighting the lack of any trace of $\mathrm{K}^{+}$, which would be the last ion to combine in this kind of brine. This is evidence of thenardite being a diagenetic product (secondary mineral) formed after a precursor mineralogy. A similar mechanism could explain the chemistry of the halite fluid inclusions, in this case being produced by the dehydration of hydrohalite, another salt formed in severe cool environments, although the origin of the halite in the Tajo basin sequence is still under study.

Consequently, based on the textural patterns of the thenardite crystals, the internal arrangements of the sedimentary structures and the ionic content of the fluid inclusions, the thenardite deposits of the Tajo basin are clearly a diagenetic product of a precursor mirabilite, which had to be formed under cool temperature conditions.

\subsection{Cool and arid climate indicator}

The Lower Unit of the Miocene in the Tajo basin ( 23$16 \mathrm{Ma}$ ) (Alberdi et al., 1984; Calvo et al., 1993) is subdi- vided into different stages based on mammal associations (Daams et al., 1997). The time span of the lower Miocene sequence of another Iberian basin (the Calatayud-Teruel basin, $200 \mathrm{~km}$ to the northeast of the Tajo basin) corresponds to Zone A ( 22-18 Ma) (Van der Meulen and Daams, 1992) established on the basis of particular stages of evolution of rodents and other species (Daams et al., 1997). The fauna from the younger part of this unit is characterized by the existence of a particular Gliridae (a dormouse) that lived in forest or open forest environments, as well as other rodent taxocenoses, which are dominated by Eomyids of the genus Ligermimys. Zone A is thought to be humid, although there is a change to drier and relatively cooler conditions towards the top of the zone $(\sim 18.4 \mathrm{Ma})$. At this moment, the number of specimens decreases significantly, and a higher percentage of Peridyromys murinus (46\%) appears, a species that shows abundance at higher latitudes because of its greater tolerance to lower temperatures than other species such as Mycrodyromys (present at $3 \%$ ), a thermophile taxon that disappears during cooling events (Daams et al., 1997). During this same time interval, in other parts of Europe, a noticeable increase in mesothermic plants and high-elevation conifers has been documented, interpreted as a result of climate cooling possibly caused by Antarctic glaciations or by uplift of surrounding mountains (Kuhlemann and Kempf, 2002; Utesche et al., 2000), a process even favored by the progressive movement of Eurasia towards northern latitudes as a result of the northward collision of Africa.

Among other characteristics, it is of great importance to point out that, during the upper part of the lower Miocene, there is a marked fauna turnover, with the appearance of new mammals such as Anchitherium, the first Proboscideans, etc. (Morales and Nieto, 1997). The existence of turnover cycles in rodent faunas from Spain (periods of 2.4 to 2.5 and $1 \mathrm{Ma}$ ) appears related to low-frequency modulations of Milankovitch-controlled climate oscillation (Van Daam et al., 2006). The Earth's climate and its evolution, studied by the analysis of deep-sea sediment cores, experience gradual trends of warming and cooling, with cycles showing $10^{4}$ to $10^{6}$ years of rhythmic or periodic cyclicality explained as related to variations in orbital parameters such as eccentricity, obliquity and precession that affect the distribution and amount of incident solar energy (Zachos et al., 2001). Obliquity nodes and eccentricity minima are associated with ice sheet expansion in Antarctica that altered precipitation regimes together with cooling and aridity. These climatic changes produce perturbations in terrestrial biota through reduced food availability (Kuhlemann and Kempf, 2002; Utesche et al., 2000; Van Daam et al., 2006).

The Oligocene-Miocene boundary ( $\sim 23 \mathrm{Ma}$ ) corresponds to a brief ( $\sim 200 \mathrm{kyr})$, but deep, Antarctic glacial maximum, referred to as Mi-1 (Fig. 5), followed by a series of intermittent but smaller phases of glaciation (Mi events) where maximum ice volume took place on a scale of over $100 \mathrm{kyr}$ on the East Antarctic continent (Mawbey and Lear, 2013). The 
Mi- 1 event was accompanied by a series of accelerated rates of turnover and speciation in certain groups of biota, such as the extinction of Caribbean corals at this boundary. This limit is accompanied by sharp positive carbon isotope excursions that suggest perturbations of the global carbon cycle (Fig. 5). Correlating the $\delta^{18} \mathrm{O}$ and $\delta^{13} \mathrm{C}$ values of deep-sea sediment cores with sea-level calibrations has shown that, during the early Miocene, the ice volume ranged from 50 to $125 \%$ of the present day volume (Pekar and DeConto, 1996). Tectonic changes such as the opening of the Drake Passage may have modified portions of the planet's ocean circulation system, promoting synchronous global cooling trends (Coxall et al., 2005). The cold water from the southern Atlantic and abyssal Pacific basins (Lear et al., 2004) mixed with a warm deep-water mass located in the Atlantic and Indian oceans (Billups et al., 2002; Wright and Miller, 1996). Wright and Colling (1995) estimated that, during these glacial periods, there was a temperature gradient of up to $6^{\circ} \mathrm{C}$, larger than observed today $\left(\sim 3-4^{\circ} \mathrm{C}\right)$. The influence of this temperature drop on a global scale could have had some influence on the precipitation of cryophilic and even cryogenic salts from salt-concentrated brines during these particular moments at the Iberian Peninsula latitudes.

Hence, in the upper part of the sedimentary sequence of the Lower Unit, the presence of a higher proportion of species with high tolerance to cool climatic conditions, and the lowering of the individual count and species variety, indicate the existence of a climatic change into a cool and arid period within the Iberian Peninsula ( $\sim 18.4 \mathrm{Ma})$. This age appears to coincide with a global Mi-1ab event (Miller et al., 1991) that represented an interval of ice expansion, at least in East Antarctica. The global low temperature and arid conditions of the environment could have been magnified in this area by its continental character and the regional uplift of the surrounding mountains that left this area at a higher altitude and within a "rain shadow" region. In addition, recycling of ancient saline formations provides concentrated brines that promote the precipitation of mirabilite at even higher temperatures. Higher up in the sequence, the gypsum deposits formed by evaporative concentration of the saline brines as a result of the climate warming indicated the temperature curves that show the trend towards the Miocene optimum (Zachos et al., 2001).

\section{Conclusions}

The appearance of thick, pure thenardite beds in the geological record can be used as a paleoclimate indicator of cool and arid periods. By fieldwork analysis and laboratory techniques, we have described a way to establish the diagenetic character of the thenardite deposits formed after a mirabilite precursor, a salt that is well known to form under cool and arid weather conditions. Mirabilite deposits require a sustained period of time to develop, with a fairly continuous, persistent period of a cool climate because it is normally formed during a frigid-concentration process. This mechanism of formation has led to the development of a typical salt paragenesis, and its fingerprint is recorded within the geochemistry of its fluid inclusions.

The establishment of the age of this unit, based on mammal assemblages, has permitted us to determine the existence of a relatively cool and dry period from a lacustrine record that correlates with an Antarctic ice expansion "Mi" event (Mi-1ab that took place at $\sim 18.4 \mathrm{Ma}$ ) determined from marine deposits and established on a global scale by isotope studies. This period represents a moment of the expansion of, at least, the East Antarctic ice sheet. This expansion has been interpreted as being related to changes in the Earth's orbital parameters such as obliquity and eccentricity that even control the turnover cycles of different biotas, as appears to be the case in the Iberian Peninsula. Therefore, the correlation of terrestrial and marine records contributes to a more precise knowledge of environmental and climatic changes on a global scale.

Hence, the lacustrine deposits of the upper part of the Lower Unit of the Tajo Miocene succession do not require a regressive sequence of a lacustrine system due to the reduction of water by desiccation alone (due to intense evaporation). Instead, the mirabilite was formed in a lake with high $\mathrm{Na}^{+}$and $\mathrm{SO}_{4}^{2-}$ saturated waters. At a time period where temperature was subject to a significant decrease and aridity became a key factor $(\sim 18.4 \mathrm{Ma})$, the brines were concentrated by a cooling-freezing mechanism that led to the formation of thick well-differentiated mirabilite layers, which later were diagenetically transformed to thenardite.

Acknowledgements. We would like to thank the SAMCA company, and especially Francisco Gonzalo and Carlos Lasala, for providing the necessary samples (drilling cores and mine samples) employed in this research and for their encouragement. Special thanks to M. E. Arribas, M. A. Alvarez, the editor Y. Godderis and the reviewers C. Monnin and S. Bourquin for their comments and suggestions that have led to improvements in the manuscript. This study was financed by the Fundación General de la Universidad Complutense de Madrid (projects 396/2009-4153239 and 139/2014-4155418).

Edited by: Y. Godderis

\section{References}

Alberdi, M. T., Hoyos, M., Junco, F., López-Martínez, N., Morales, J., Sesé, C., and Soria, D.: Biostratigraphy and sedimentary evolution of continental Neogene in the Madrid area, Paléobiol. Continent., 14, 47-68, 1984.

Ayllón-Quevedo, F., Souza-Egipsy, V., Sanz-Montero, M. E., and Rodriguez-Aranda, J. P.: Fluid inclusion analysis of twinned selenite gypsum beds from the Miocene of the Madrid basin 
(Spain), Implication on dolomite bioformation., Sediment. Geol., 201, 212-230, 2007.

Ayora, C., García-Veigas, J., and Pueyo Mur, J. J.: X-ray microanalysis of fluid inclusions and its application to the geochemical modelling of evaporite basins, Geochim. Cosmochim. Ac., 58, 43-55, 1994.

Babel, M. and Schreiber, B. C.: Geochemistry of Evaporites and Evolution of Seawater. In: Treatise on Geochemistry (Second Edition), edited by: Turekian, K. and Holland, H., Elsevier, Oxford, 2014.

Billups, K., Channell, J. E. T., and Zachos, J.: Late Oligocene to early Miocene geochronology and paleoceanography from the subantarctic South Atlantic, Paleoceanography, 17, 4.1-4.11, 2002.

Borchert, H. and Muir, R. O.: Salt Deposits. The Origin, Metamorphism and Deformation of Evaporites, D. Van Nostrand Company, London, 1964.

Brasier, A. T.: Searching for travertines, calcretes and speleothemes in deep time: Processes, appearances, predictions and the impact of plants, Earth-Science Reviews, 104, 213-239, 2011.

Calvo, J. P., Daams, R., Morales, J., López-Martínez, N., Agustí, J., Anadón, P., Armenteros, I., Cabrera, L., Civis, J., Corrochano, A., Díaz-Molina, M., Elizaga, E., Hoyos, M., Martín-Suarez, E., Martínez, J., Moissenet, E., Muñoz, A., Pérez-García, A., PérezGonzález, A., Portero, J. M., Robles, F., Santisteban, C., Torres, T., Van der Meulen, A., Vera, J. A., and Mein, P.: Up-to-date Spanish continental Neogene synthesis and paleoclimatic interpretation, Revista de la Sociedad Geológica de España, 6, 29-40, 1993.

Calvo, J. P., Alonso-Zarza, A. M., García del Cura, M. A., Ordoñez, S., Rodriguez-Aranda, J. P., and Sanz-Montero, M. E.: Sedimentary evolution of lake systems through the Miocene of the Madrid Basin: paleoclimatic and paleohydrological constraints, in: Tertiary basins of Spain, the stratigraphic record of crustal kinematics, edited by: Friend, P. F. and Dabrio, C. J., Cambridge University Press, Cambridge, 1996.

Calvo, J. P., Ordoñez, S., García del Cura, M. A., Hoyos, M., Alonso-Zarza, A. M., Sanz, E., and Rodriguez, J. P.: Sedimentología de los complejos lacustres miocenos de la Cuenca de Madrid, Acta Geol. Hisp., 24, 281-298, 1989.

Cañaveras, J. C., Sánchez-Moral, S., Calvo, J. P., Hoyos, M., and Ordóñez, S.: Dedolomites associated with karstic features, an example of early dedolomitization in lacustrine sequences from the Tertiary Madrid Basin, Central Spain., Carb. Evaporit., 11, 85103, 1996.

Chaboureau, A.-C., Donnadieu, Y., Sepulchre, P., Robin, C., Guillocheau, F., and Rohais, S.: The Aptian evaporites of the South Atlantic: a climatic paradox?, Clim. Past, 8, 1047-1058, doi:10.5194/cp-8-1047-2012, 2012.

Charykova, M. V., Kurilenko, V. V., and Charykov, N. A.: Temperatures of formation of certain salts in sulfate-type brines, J. Appl. Chem. USSR, 65-1, 1037-1040, 1992.

Chun, F. H.: Quantitative interpretation of X-ray diffraction patterns of mixtures, III. simultaneous determination of a set of reference intensities, J. Appl. Chrystallogr., 8, 17-19, 1975.

Coxall, H. K., Wilson, P. A., Palike, H., Lear, C. H., and Backman, J.: Rapid stepwise onset of Antarctic glaciation and deeper calcite compensation in the Pacific Ocean, Nature, 433, 53-57, 2005.
Daams, R. and Freudenthal, M.: Synopsis of the Dutch-Spanish collaboration program in the Aragonian type area, 1975-1986, in: Biostratigraphy and paleoecology of the Neogene micromammalian faunas from the Calatayud-Teruel Basin (Spain), Scripta Geológica, Spec. Issue, 1, 3-18, 1988.

Daams, R., Álvarez-Sierra, M. A., Van der Meulen, A., and PeláezCampomanes, P.: Los micromamíferos como indicadores de paleoclimas y evolución de las cuencas continentales, in: Registros fósiles e Historia de la Tierra, edited by: Aguirrre, E., Morales, J., and Soria, D., Editorial Complutense, Madrid, 1997.

De Vicente, G., González-Casado, J. M., Muñoz-Martín, A., Giner, J. L., and Rodríguez-Pascua, M. A.: Structure and Tertiary evolution of the Madrid basin, in: Tertiary basins of Spain, the stratigraphic record of crustal kinematics, edited by: Friend, P. F. and Dabrio, C. J., Cambridge University Press, Cambridge, 1996.

Dort, W. J. and Dort, D. S.: Low Temperature Origin of Sodium Sulfate Deposits, Particularly in Antarctica, in: Third Symposium on Salt, 1, Ohio Geological Society, 1970.

Escavy, J. I., Herrero, M. J., and Arribas, M. E.: Gypsum resources of Spain: Temporal and spatial distribution, Ore Geol. Rev., 49, 72-84, 2012.

Eugster, H. P. and Hardie, L. A.: Saline Lakes ,in: Lakes, Chemistry, Geology, Physics, edited by: Lerman, A., Springer Verlag, 237293, 1978.

Fan-Wei, M., Pei, N., Xun-Lai, Y., Chuan-Ming, Z., Chun-He, Y., and Yin-Ping, L.: Choosing the best ancient analogue for projected future temperatures: A case using data from fluid inclusions of middle-late Eocene halites, J. Asian Earth Sci., 67/68, 46-50, 2013

Garrett, D.: Sodium Sulfate. Handbook of Deposits, Processing, and Use, Academic Press, San Diego, 2001.

Goldstein, R. H. and Reynolds, T. J.: Systematics of Fluid Inclusions in Diagenetic Minerals, Society for Sedimentary Geology, Tulsa, USA, 1994.

Haq, B. U., Hardenbol, J., and Vail, P. R.: Chronology of fluctuating sea levels since the Triassic 250 million years ago to present, Science, 235, 1156-1167, 1987.

Hardie, L. A. and Eugster, H. P.: The evolution of closed-basin brines, Mineral. Soc. Am. Spec. Paper 3, 1970, 273-290, 1970.

Harvie, C. E., Weare, J. H., Hardie, L. A., and Eugster, H. P.: Evaporation of sea-water: calculated mineral sequences, Science, 208, 498-500, 1980.

Herrero, M. J., Escavy, J. I., and Bustillo, M.: The Spanish building crisis and its effect in the gypsum quarry production (19982012), Resour. Pol., 38, 123-129, 2013.

Hovland, M., Rueslatten, H., Johnsen, H. K., Kvamme, B., and Kuznetsova, T.: Salt formation associated with sub-surface boiling and supercritical water, Mar. Petrol. Geol., 23, 855-869, 2006.

Jones, B.: The Hydrology and Mineralogy of Deep Springs Lake, Inyo County, California, United States Government, Washington, 1965.

Kendall, A. C.: Evaporites, in: Facies Models, Respons to sea level changes, Walker, R. G. and James, N. P., Geological Association of Canada, St John's, 1992.

Kuhlemann, J. and Kempf, O.: Post-Eocene evolution of the North Alpine Foreland, Sediment. Geol., 152, 45-78, 2002.

Last, W. M.: Modern sedimentology and hydrology of Lake Manitoba, Canada, Environ. Geol., 5, 177-190, 1984. 
Last, W. M.: Deep-water evaporite mineral formation in lakes of western canada, in: Sedimentology and geochemistry of modern and ancient saline lakes, edited by: Renant, R. and Last, W., SEPM, Tulsa, Oklahoma, 51-59, 1994.

Lear, C. H., Rosenthal, Y., Coxall, H. K., and Wilson, P. A.: Late Eocene to early Miocene ice sheet dynamics and the global carbon cycle, Paleoceanography, 19, PA4015, doi:10.1029/2004PA001039, 2004.

Lowenstein, T. K. and Hardie, L. A.: Criteria for the recognition of salt-pan evaporites, Sedimentology, 32, 627-644, 1985.

Lowenstein, T. K., Jianren, L., Brown, C., Roberts, S. M., TehLung, K., Shangde, L., and Wembo, Y.: 200 k.y. paleoclimate record from Death Valley salt core, Geology, 27, 3-6, 1999.

Magny, M. and Combourieu Nebout, N.: Holocene changes in environment and climate in the central Mediterranean as reflected by lake and marine records, Climate of the Past, 9, 1447-1454, doi:10.5194/cp-9-1447-2013, 2013.

Marion, G. M., Farren, R. E., and Komrowski, A. J.: Alternative pathways for seawater freezing, Cold Reg. Sci. Technol., 29, 259-266, 1999.

Mawbey, E. M. and Lear, C. H.: Carbon cycle feedbacks during the Oligocene-Miocene transient glaciation, Geology, 41, 963-966, 2013.

Miller, K. G., Wright, J. D., and Fairbanks, R. G.: Unlocking the Ice House: Oligocene-Miocene oxygen isotopes, eustasy, and margin erosion, J. Geophys. Res., 96, 6829-6848, 1991.

Minghui, L., Xiaomin, F., Chaulou, Y., Shaopeng, G., Weilin, Z., and Galy, A.: Evaporite minerals and geochemistry of the upper $400 \mathrm{~m}$ sediments in a core from the Western Qaidam Basin, Tibet, Quaternary Internat., 218, 176-189, 2010.

Möhlmann, D. and Thomsen, K.: Properties of cryobrines on Mars, Icarus, 212, 123-130, 2011.

Morales, J. and Nieto, M.: El registro terciario y cuaternario de los mamíferos de España, in: Registros fósiles e Historia de la Tierra, edited by: Calvo, J. P. and Morales, J., Editorial Complutense, Madrid, 297-322, 1997.

Mullin, J. W.: Crystallization, 4th Edition, Butlerworth-Heinemann, Oxford, 2001.

Nai'ang, W., Zhuolun, L., Yu, L., Hongyi, C., and Rong, H.: Younger Dryas event recorded by the mirabilite deposition in Huahai lake, Hexi Corridor, NW China, Quaternary International, 250, 93-99, 2012.

Nakhla, F. M., Saleh, S. A., and Gad, N. L.: Mineralogy, chemistry and paragenesis of the thenardite $\left(\mathrm{Na}_{2} \mathrm{SO}_{4}\right)$, in: Applied Mineralogy, The Metallurgical Society of AIME, New York, 1985.

Ordóñez, S., Calvo, J. P., García del Cura, M. A., Alonso-Zarza, A. M., and Hoyos, M.: Sedimentology of sodium sulphate deposits and special clays from the Tertiary Madrid Basin (Spain), in: Lacustrine Facies Analysis, edited by: Anadón, P., Cabrera, L., and Kelts, K., Special Publications of the International Association of Sedimentologists, Wiley, 1991.

Ordoñez, S. and García del Cura, M. A.: Deposition and diagenesis of sodium-calcium sulfate salts in the tertiary saline lakes of the Madrid Basin, Spain, in: Sedimentology and Geochemistry of Modern and Ancient Saline Lakes, SEPM Spec. Publ., 50, 229238, 1994.

Ortí, F.: Evaporitas: Introducción a la sedimentología evaporítica, in: Sedimentología, edited by: Arche, A., 675-770, 2010.
Ortí, F., Pueyo, J. J., and San Miguel, A.: Petrogénesis del yacimiento de sales sódicas de Villarubia de Santiago, Toledo (Terciario continental de la Cuenca del Tajo), Boletín Geológico y Minero, T. XC, 347-373, 1979.

Ortí, F., Gündogan, I., and Helvaci, C.: Sodium sulphate deposits of Neogene age: the Kirmir Formation, Beypazari Basin, Turkey, Sediment. Geol., 146, 305-333, 2002.

Pekar, S. F. and DeConto, R. M.: High-resolution ice-volume estimates for the early Miocene: Evidence for a dynamic ice sheet in Antarctica, Palaeogeography, Palaeoclimatology, Palaeoecology, 231, 101-109, 1996.

Peterson, R. C., Nelson, W., Madu, B., and Shurvell, H. F.: Meridianiite: A new mineral species observed on Earth and predicted to exist on Mars, Am. Mineral., 92, 1756-1759, 2007.

Rouchy, J. M. and Blanc-Valleron, M. M.: Les évaporites: materiaux singuliers, millieux extrèmes, Vuibert, Société géologique de France, Paris, 2009.

Salvany, J. M. and Ortí, F.: Miocene glauberite deposits of Alcanadre, Ebro Basin, Spain: Sedimentary and diagenetic processes, in: Sedimentology and Geochemistry of Modern and Ancient Saline Lakes, SEPM Spec. Publ. 50, edited by: Renault, R. W. and Last, W. M., Tulsa, EEUU, 203-215, 1994.

Salvany, J. M., García-Veigas, J., and Ortí, F.: Glauberite-halite association of the Zaragoza Gypsum Formation (Lower Miocene, Ebro Basin, NE Spain, Sedimentology, 54, 443-467, 2007.

Sánchez-Moral, S., Ordóñez, S., Benavente, D., and García del Cura, M. A.: The water balance equations in saline playa lakes: comparison between experimental and recent data from Quero Playa Lake (central Spain), Sediment. Geol., 148, 221-234, 2002.

Schreiber, B. C. and El Tabakh, M.: Deposition and early alteration of evaporites, Sedimentology, 47, 215-238, 2000.

Shortland, A. J.: Evaporites of the Wadi Natrun: Seasonal and annual variation and its implication for ancient exploitation, Archaemetry, 46, 497-516, 2004.

Socki, R. A., Sun, T., Niles, P. B., Harvey, R. P., Bish, D. L., and Tonui, E.: Anctarctic Mirabilite Mounds as Mars Analogs: The Lewis Cliffs Ice Tongue Revisited, The Woodlands, Texas2012, 2012.

Stankevich, E. F., Batalin, Y. V., and Sinyavskii, E. I.: Sedimentation and dissolution of salts during fluctuations of the brine level in a self-sedimenting lake, Geol. Geofiz, 3, 35-41, 1990.

Stark, S. C., O'Grady, B. V., Burton, H. R., and Carpenter, P. D.: Frigidly concentrated seawater and the evolution of Antarctic saline lakes, Australian J. Chem., 56, 181-186, 2003.

Stewart, F. H.: Marine Evaporites, in: Data of Geochemistry, edited by: Fleischer, M., US Geological Survey, Washington, 1963.

Strakhov, N. M.: Principles of lithogenesis, Plenum Publishing Corporation, New York, 1970.

Utesche, T., Mosbrugger, V., and Ashraf, A.: Terrestrial Climate Evolution in Northwest Germany Over the Last 25 Million Years, PALAIOS, 15, 430-449, 2000.

Van Daam, J. A., Abdul-Aziz, H., Álvarez-Sierra, M. A., Hilgen, F. J., Van de Hoek Ostende, L. W., Lourens, L. J., Mein, P., Van der Meulen, A., and Pelaez-Campomanes, P.: Long-period astronomical forcing of mammal turnover, Nature, 443, 687-691, 2006.

Van der Meulen, A. and Daams, R.: Evolution of Early-Middle Miocene rodent faunas in relation to long-term palaeoenviron- 
mental changes, Palaeogeography, Palaeoclimatology, Palaeoecology, 93, 227-253, 1992.

Wang, N., Zhang, J., Cheng, H., Guo, J., and Zhao, Q.: The age of formation of the mirabilite and sand wedges in the Hexi Corridor and their paleoclimatic interpretation, Chinese Sci. Bull., 48, 1439-1445, 2003.

Warren, J.: Evaporites: Sediments, Resources and Hydrocarbons, Springer, Berlin, 2006.

Warren, J.: Evaporites through Time: Tectonic, climatic and eustatic controls in marine and nonmarine deposits, Elsevier, 2010.

Wright, J. D. and Colling, A.: Seawater: its composition, properties, and behaviour, Open University Press and Elsevier, Oxford, 1995.
Wright, J. D. and Miller, K. G.: Control of North Atlantic deep water circulation by the Greenland-Scotland Ridge, Paleoceanography, 11, 157-170, 1996.

Zachos, J., Pagani, M., Sloan, L., Thomas, E., and Billups, K.: Trends, Rhythms, and Aberrations in Global Climate $65 \mathrm{Ma}$ to Present, Science, 292, 686-693, 2001.

Zheng, M., Zhao, Y., and Liu, J.: Palaeoclimatic Indicators of China's Quaternary Saline Lake Sediments and Hydrochemistry, Acta Geologica Sinica, 74, 259-265, 2000. 